\title{
Prevalence of cryptococcal meningitis and lymphadenitis among PLHA
}

\author{
MV Narasimham*, Pritilata Panda \\ From 2nd International Science Symposium on HIV and Infectious Diseases (HIV SCIENCE 2014) \\ Chennai, India. 30 January - 1 February 2014
}

\section{Background}

Cryptococcosis has been a common cause of morbidity and mortality in immunocompromised patients. This study was conducted to estimate the prevalence of cryptococcosis in PLHA cases presenting mainly with meningitis and lymphadenitis.

\section{Methods}

An ongoing prospective study conducted from June 2012- October 2013 in 90 HIV seropositive patients presenting with various complaints. CSF and lymphnode aspirates were subjected to preliminary microscopic examination, c (Giemsa staining, mucicarmine staining, negative staining and Gram's staining). Latex agglutination test was done for CSF samples. Sampls inoculated on SDA at $37^{\circ} \mathrm{C}$ and $25^{\circ} \mathrm{C}$ followed by Bird seed agar (BSA). Identification was done based on demonstration of encapsulated budding yeast cells in microscopy, negative staining with Nigrosin, red capsule on mucicarmine, yeast like creamy mucoid colony on SDA at $37^{\circ} \mathrm{C}$, brown to black colony on BSA, inositol assimilation and positive urease test.

\section{Results}

Maximum cases were between 25-40 years of age. 4 meningitis \& 2 lymphadenitis cases showed positive cryptococcal growth on microscopy and culture. Both CSF and lymph node aspirate were found to be positive in 1 (1.11\%) case. 2 cases of disseminated cryptococcosis were seen with one involving multiple lymph nodes \& other was a case of meningitis \& lymph node involvement. All the positive cryptococcal cases had a CD4 count $<200$ cells/ $\mu$ l.

\section{Conclusion}

Cryptococcal infections without treatment have a high morbidity rate and appropriate systemic antifungal therapy can significantly improve the outcome. A high index of clinical suspicion and mycological surveillance is required to help in an early diagnosis \& treatment.

Published: 27 May 2014

doi:10.1186/1471-2334-14-S3-P77

Cite this article as: Narasimham and Panda: Prevalence of cryptococcal meningitis and lymphadenitis among PLHA. BMC Infectious Diseases 2014 14(Suppl 3):P77.

* Correspondence: mayurdr9.praraj@yahoo.in

PG Department of Microbiology, MKCG Medical College \& Hospital,

Submit your next manuscript to BioMed Central and take full advantage of:

- Convenient online submission

- Thorough peer review

- No space constraints or color figure charges

- Immediate publication on acceptance

- Inclusion in PubMed, CAS, Scopus and Google Scholar

- Research which is freely available for redistribution
() Biomed Central
C Biomed Central

() 2014 Narasimham and Panda; licensee BioMed Central Ltd. This is an Open Access article distributed under the terms of the Creative Commons Attribution License (http://creativecommons.org/licenses/by/4.0), which permits unrestricted use, distribution, and reproduction in any medium, provided the original work is properly cited. The Creative Commons Public Domain Dedication waiver (http://creativecommons.org/publicdomain/zero/1.0/) applies to the data made available in this article, unless otherwise stated. 